\title{
Orientation of elvers of American eels (Anguilla rostrata) in weak magnetic and electric fields
}

\author{
M. A. Zimmerman \& J. D. McCleave \\ Migratory Fish Research Institute and Department of Zoology, \\ University of Maine; Orono, Maine, USA
}

\begin{abstract}
KURZFASSUNG: Orientierung von Jungtieren des Amerikanischen Aales (Anguilla rostrata) in schwachen magnetischen und elektrischen Feldern. Amerikanische Jungaale (Anguilla rostrata) wurden im Süßwasser auf ihre Sensitivität gegenüber natürlich vorkommenden magnetischen Feldern geprüft. Die Richtungsänderungen in einem runden Arenafeld wichen bei diesen Tieren nicht voneinander ab, gleichgültig ob das horizontale Magnetfeld parallel oder senkrecht zu ihrer Körperachse angelegt worden war. Unterschiede in ihrer Richtungswahl in dem nördlich, östlich, südlich oder westlich ausgerichteten Arenafeld oder in einem Irrgartenversuch bei ost-westlich, nordnordost-südsüdwestlich und nordnordwest-südsüdöstlich offenstehenden Gängen traten nicht auf. Schließlich war die Richtungswahl bei beiden Versuchsmethoden unverändert, wenn das horizontale Magnetfeld der Erde kompensiert worden war. Diese Ergebnisse zeigen, daß die Jungaale sich nicht nach dem horizontalen Vektor des Erdmagnetfeldes orientierten. Sie stehen damit im Gegensatz zu den Resultaten neuerer russischer und deutscher Untersuchungen an Europäischen Jungaalen (Anguilla anguilla). Amerikanische Jungaale richteten sich dagegen in einem rechteckigen Arenafeld sowohl im Süß- als auch im Seewasser zur Anode eines horizontalen elektrischen Feldes aus, und zwar um so mehr, je stärker dieses Feld angelegt worden war. Umkehrung der Polarität des elektrischen Feldes erwirkte auch Umkehrung der Richtungswahl der Aale. In den meisten Fällen war die Feldintensität etwas höher, als normalerweise im Meer durch magneto-hydrodynamische Effekte zu erwarten ist. Diese vorläufigen Ergebnisse legen es nahe, daß Aale elektrische Felder für ihre Orientierung im Ozean nutzen. Eine beträchtliche Anzahl von Aalen orientierte sich im Irrgartenversuch stärker nach rechts oder nach links, gleichgültig ob das Magnetfeld normal oder verändert war. Es kann nicht ausgeschlossen werden, daß dieses Phänomen einer „Rechtsbzw. Linkslastigkeit" ein Artefakt der hier benutzten Versuchsanordnung darstellt; eine tatsächlich vorhandene magnetische Orientierung könnte dadurch überdeckt worden sein,
\end{abstract}

\section{INTRODUCTION}

The near-shore migration of elvers of American and European eels, Anguilla rostrata and $A$. anguilla, has been the subject of limited research. Laboratory studies by Creutzberg $(1958,1959,1963)$ and Mrles (1968) revealed that the orientation mechanism in coastal and estuarine waters depends upon an olfactory response to unidentified organic fractions in the water.

The oceanic phase of elver migration, however, has received little attention. The leptocephalus larvae of both species move from the spawning grounds in the southern 
North Atlantic to their respective continents apparently by passive transport in ocean currents (HARDEN JONES, 1968). Following metamorphosis on the continental shelf (BERTIN, 1956), the glass eels (unpigmented elvers) contribute to the final stages of migration by their increased powers of locomotion (DEELDER, 1952). In fact the possibility of an active element to leptocephalus migration cannot be ruled out.

Active migration suggests an orientational ability. Numerous orientation mechanisms based on a variety of environmental stimuli have been advanced both for elvers and adult eels. Among these is the hypothesis that the earth's magnetic field provides directional information for open ocean migration. This information could be detected by oceanic fishes in one of three ways.

A compass reference direction could be determined directly from the magnetic field forces. The recent works of Tesch \& LELEK (1973a, b) and TEsCH (1974) on elvers and adults of the European eel tend to support this hypothesis; however, Rommel \& McCleave (1973a) published negative evidence for American eels.

Indirect information could be derived from electromotive forces produced by the motion of an electric conductor through a magnetic field. REgNART (1932) and Royce et al. (1968) proposed that the electric fields generated by movement of ocean currents through the earth's magnetic field provide orientational cues for migrating fish. RomMEL \& MCCleave $(1972,1973$ a) demonstrated that American eels, and Atlantic salmon (Salmo salar) are sensitive to weak electric fields of the order found in ocean currents. They also provided a discussion of this hypothesis together with predicted values of electric fields in ocean current systems (Rommel \& MCCleAve, 1973b).

A variant of this hypothesis is that the fish's own motion through the earth's magnetic field produces detectable electric potentials within its body (THORNTON 1932; MurRay 1962). Evidence in support and a theoretical discussion of this hypothesis with reference to the European elver was presented by BRANOVER et al. (1971).

Further evidence that the earth's magnetic field is involved in orientation of the European eel was given by Gleyzer \& KHodorkovskiy (1971), Gleyzer (1971) and Branover et al. (1971) who found that a nonrandom directional orientation of elvers in a maze degenerated to random when the horizontal and vertical components of geomagnetism were compensated. TESCH (1974) reported an alteration of preferred direction of adult eels when the horizontal component was reduced to near zero. KHodorkovskiy \& Polonnikov (1971) also found altered directional behavior of elvers when the geomagnetic field was reversed.

In view of the differing claims of whether and how the earth's magnetic field influences eel orientation, and of the possible differences in responses between the two species, further testing of the magnetic and electric field sensitivity of both American and European eels is needed. Consequently this study was undertaken to determine (1) if elvers of American eels orient to the earth's magnetic field, (2) if such orientation depends upon the horizontal component of the magnetic field, and (3) if elvers orient to weak d.c. electric fields. Experiments examining the latter are preliminary. The data were also examined to determine whether elvers exhibit right or left turning preferences ("handedness"). 


\section{MATERIAL AND METHODS}

Two approaches previously tested in other laboratories were used in this study. The first measured the turning angles of elvers in an apparatus modified from the work of Brown (e. g. Brown et al., 1960). The second examined directional choices made by slightly older elvers in a hexagonal maze employed by Branover et al. (1971) and GLEYZER \& KHODORKOVSKIY (1971).

Experiments using the first approach to study orientation to a magnetic field were conducted between 19 June and 28 September 1973, and to an electric field between

A
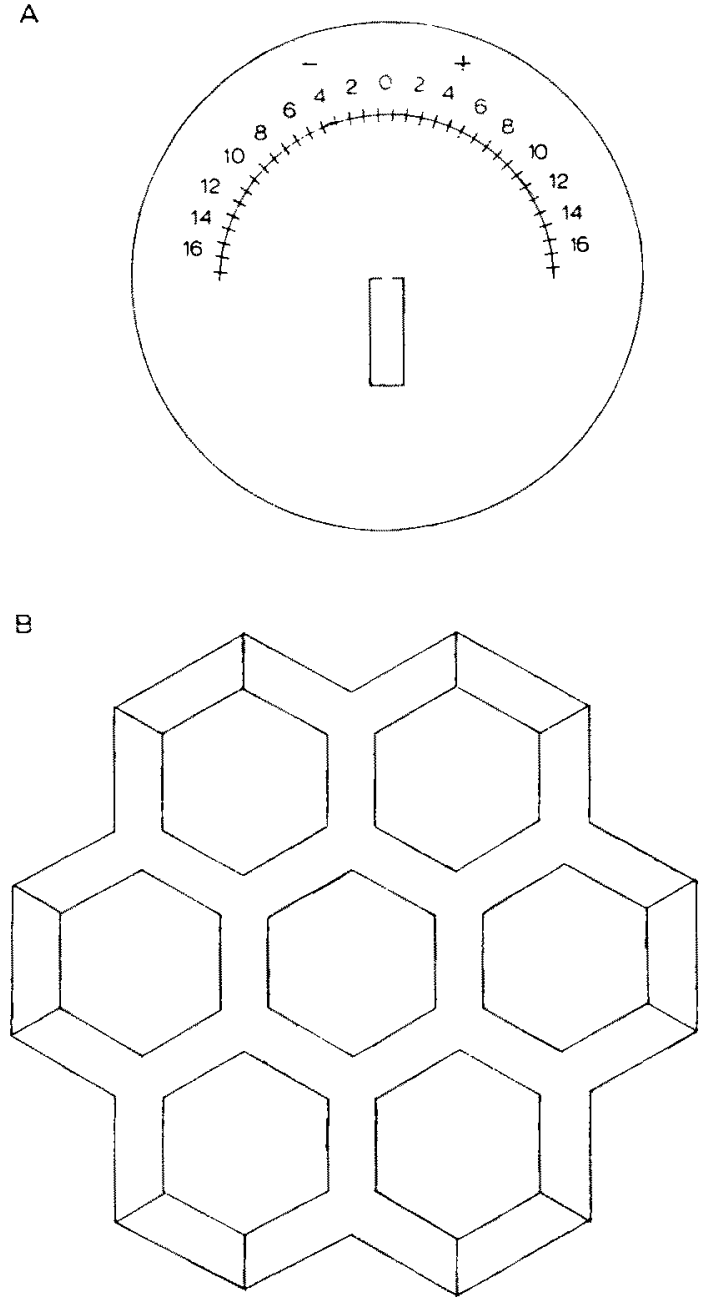

Fig. 1: The apparatus used to test orientation of elvers of American eels in weak magnetic fields. (A) The circular arena used to measure turning angles. (B) The maze used to measure directional choices 
5 June and 23 August 1974. The apparatus for the magnetic field tests (Fig. 1A) consisted of a circular polyethylene ring $46 \mathrm{~cm}$ in diameter and $9 \mathrm{~cm}$ deep mounted on a plexiglass base. A plexiglass release box $10 \times 3 \mathrm{~cm}$ was positioned with the door at the center of the tank. An arc $15 \mathrm{~cm}$ from the release point was divided into $35,5^{\circ}$ intervals. The middle interval was designated 0 and aligned with the test directions (e.g., magnetic north). The apparatus was the same for electric field experiments except the circular ring was replaced by a $50 \times 50 \mathrm{~cm}$ square plexiglass box $7.5 \mathrm{~cm}$ deep. A pair of stainless steel electrodes, $50 \times 7.5 \mathrm{~cm}$, was glued inside the side walls. The apparatus was filled with $3 \mathrm{~cm}$ of well water.

The apparatus was placed inside a white chamber to eliminate asymmetry in the visual field. A single incandescent light bulb hanging directly over the release point provided illumination of $360 \mathrm{lux}$ in the magnetic field experiments. A small bulb provided illumination of less than 1 lux in the electric field experiments. A $6 \times 3 \mathrm{~cm}$ observation hole was positioned above and behind the apparatus. Two Helmholtz coils $2 \mathrm{~m}$ in diameter were placed $1 \mathrm{~m}$ apart outside the observation chamber.

Elvers 6-8 cm long were collected occasionally from a small freshwater stream at Sandy Point, Waldo County, Maine. In the laboratory fish were housed in aquaria placed in a large water bath and maintained at $15 \pm 1^{\circ} \mathrm{C}$. Fish for salt water experiments were gradually acclimated to artifical sea water of about $32 \%$. Although cues of the normal light-dark cycle were present, artifical lights of the laboratory were the direct source of illumination. The fish for magnetic field experiments were fed nauplii of Artemia sp. daily and held 4-6 weeks; those for electric field experiments were not fed and were not held more than about 3 weeks.

Elvers were tested individually. Each fish was placed in the release box and allowed approximately $15 \mathrm{sec}$ to settle down. The door of the release box was removed and the observer's hand quickly withdrawn. The fish swam into the test area of the tank and the sector of the arc crossed was recorded. Fish that did not cross the $15 \mathrm{~cm}$ arc before swimming into the back half of the apparatus (the $185^{\circ}$ behind the release box) were not included in the analysis. Water temperature during test sessions ranged between 13 and $20^{\circ} \mathrm{C}$.

In most experiments elvers were generally used once in a day, although an occasional shortage necessitated a second run for some. In the reversed polarity electric field experiment, most elvers were run twice a day.

Magnetic field experiments were conducted from 1000-1200 EDT (Eastern daylight time) and from 1600-1800 EDT. The number of observations for a session was determined by the number of fish that could complete the run in the $2 \mathrm{~h}$ test session. Electric field experiments were conducted from about 1000-1500 EDT.

The first magnetic field experiment examined the turning angles of elvers when the apparatus was directed toward magnetic north and east in the earth's magnetic field. These two directions positioned the elver's body axis parallel (north) or perpendicular (east) to the $0.160-0.165$ gauss horizontal vector of the ambient magnetic field. The alignment of the apparatus was alternated at $0.5 \mathrm{~h}$ intervals. Initial alignment was chosen randomly each day.

In the next magnetic experiment turning angles were observed for elvers directed 
north, east, south and west. North and east alignments were alternated with south and west alignments on subsequent test days.

The final magnetic experiment measured the turning of elvers headed north and east in the normal magnetic field and in a field with the horizontal component reduced to $0.0 \pm .01$ gauss. From this experiment elver behavior, presumably in the presence and absence of orientational information, could be compared. The data collected under normal conditions were used to extend the first series.

The 14,218 total observations of approximately 475 different fish were statistically analyzed by computer. An analysis of variance of each of the experiments was performed. The first and third experiments were treated as $2 \times 2$ factorial designs and the second was as a $4 \times 2$ factorial.

The first two electric field experiments examined the turning angles of elvers in fresh water (conductivity $\approx 2500 \mathrm{ohm}-\mathrm{cm}$ ) and $32 \%$ artificial sea water $(\approx 25 \mathrm{ohm}$ $\mathrm{cm}$ ) in the following d. c. electric fields (Table 1):

Table 1

Electric field experiments with elvers in fresh water and artificial sea water

\begin{tabular}{|ccc|}
\hline $\begin{array}{c}\text { Electric current } \\
\text { density }\left(\mu \mathrm{A} / \mathrm{cm}^{2}\right)\end{array}$ & $\begin{array}{c}\text { Fresh water } \\
\text { electric field } \\
\text { intensity }(\mu \mathrm{V} / \mathrm{cm})\end{array}$ & $\begin{array}{c}\text { Salt water } \\
\text { electric field } \\
\text { intensity }(\mu \mathrm{V} / \mathrm{cm})\end{array}$ \\
\hline Control & Control & Control \\
$10^{-2}$ & $25 \times 10^{\circ}$ & $25 \times 10^{-2}$ \\
$10^{-1}$ & $25 \times 10^{1}$ & $25 \times 10^{-1}$ \\
$10^{9}$ & $25 \times 10^{2}$ & $25 \times 10^{0}$ \\
$10^{1}$ & $25 \times 10^{3}$ & $25 \times 10^{1}$ \\
$10^{2}$ & $25 \times 10^{4}$ & $25 \times 10^{2}$ \\
\hline
\end{tabular}

On each day 20 elvers were tested in no field (control) and in three of the five electric fields both in fresh water and in salt water. Different elvers were usually used in each of the eight conditions, and within the fresh or salt water group, elvers were chosen randomly each day for each intensity. Each day the water series to be run first was chosen randomly. The order in which the intensity groups were run was also chosen randomly each day.

A third experiment examined the turning angles of elvers in fresh water in electric fields of reversed polarity. Electric current densities used were $0.01,1.0$, and 100.0 $\mu \mathrm{A} / \mathrm{cm}^{2}$ and controls. Elvers were directed north in all electric field experiments.

A total of 8,800 observations were made on about 500 elvers. A oneway analysis of variance and Duncan's new multiple range test were performed on each of the three experiments.

Experiments employing the second approach were conducted from 19 October to 21 December 1973 using a hexagonal, plexiglass maze (Fig. 1B). The maze consisted of a total of 24 channels, each $10 \times 4 \mathrm{~cm}$, aligned with the geographic directions $\mathrm{E}-\mathrm{W}$, NNE-SSW and NNW-SSE. The outside walls of the channels were painted black to reduce reflections within the apparatus. Six $7 \mathrm{~W}$ bulbs, one over each of the six channels radiating from the center hexagon, provided light intensity of about 6 lux. This 
arrangement was designed to reduce shadows along the channel walls. The maze was filled to $3 \mathrm{~cm}$ with $18^{\circ} \mathrm{C}$ well water.

The apparatus was placed in a black cylindrical chamber with a coneshaped ceiling to remove visual disturbances. Observations were made in a darkened room through a small hole in the ceiling of the chamber to render the observer inconspicuous. Helmholtz coils $2 \mathrm{~m}$ in diameter were positioned $1 \mathrm{~m}$ apart outside the chamber.

Elvers were collected as above. Ten were held individually in 4 liter jars in a water bath maintained at $18.0 \pm 1.0^{\circ} \mathrm{C}$. Elvers were kept in a LD $12: 12$ regime with lights on at 0600 EDT.

Elvers $9.0-16.3 \mathrm{~cm}$ long were tested individually. A 1-2 min period of adaptation to the tank preceded a 5 min test trial. The sequence of channel appearances made by an eel was spoken into a tape recorder. An appearance was defined as movement that resulted in the fish's head reaching the mid point of a channel.

During a session 10 eels were tested in the earth's normal magnetic field and then retested in a field with the horizontal component reduced to $0.0 \pm .01$ gauss. The order in which these fields were applied was chosen randomly every day. Likewise, the order in which the animals were tested was determined randomly and the order repeated for the second field of a day. A session was started at 1000 EDT and required 2.5-3.0 h for completion.

Five groups of 10 elvers were tested 10 separate days each. Elvers were held in the laboratory for 21 days or less, and were not fed.

The number of appearances in channels corresponding to the three geographic directions, E-W, NNE-SSW and NNW-SSE, were compiled for each individual trial. Chi-square values were calculated from the daily totals for each individual to test the null hypothesis that there were no differences in the number of appearances in these directions. A 10 day total for each eel was used to compute a Chi-square value for appearances in the three directions in the earth's normal magnetic field and in the field with the horizontal vector negated.

Numbers of left and right turns were also tallied for each individual each day. Chi-square values from these totals were computed for individual trials and for the composite data as above. In addition the sequence of turns was tested for the number of runs of right and left turns to test for randomness (SoKal \& RohLF 1969).

\section{RESULTS}

\section{Turning angles, magnetic field}

Elvers directed toward different geographic directions in the earth's normal magnetic field exhibited no differences in turning behavior. An analysis of variance on the long series of north and east data for morning and afternoon sessions showed that there were no significant differences in turning angles (Experiment I, Table 2). The small deviations of the mean turning angles from $0^{\circ}$ and the large variation of the data show that the eels did not discriminate between magnetic fields in which the horizontal vector was parallel to the body axis and the ones in which the horizontal vector was perpendicular to it. 
Elvers headed north, east, south and west showed no significant differences in turning behavior, indicating that they did not distinguish different geographic directions (Experiment II, Table 2).

Table 2

Turning angles of elvers in a normal magnetic field and in a field with the horizontal vector negated. Turning to the right of $0^{\circ}$ is indicated by positive means, and to the left by negative means

\begin{tabular}{|c|c|c|c|c|}
\hline Test group & $\begin{array}{l}\text { Horizontal } \\
\text { geomagnetic } \\
\text { vector }\end{array}$ & $\begin{array}{l}\text { Number of } \\
\text { observations }\end{array}$ & $\begin{array}{l}\text { Mean } \\
\text { angles }\end{array}$ & $\begin{array}{l}\text { Standard } \\
\text { deviation }\end{array}$ \\
\hline \multicolumn{5}{|c|}{ Experiment I (19 June - 28 September, 1973) } \\
\hline East AM & normal & 2435 & $-3.00^{\circ}$ & $39.79^{\circ}$ \\
\hline East PM & normal & 2349 & $-2.60^{\circ}$ & $39.38^{\circ}$ \\
\hline North AM & normal & 2425 & $-0.64^{\circ}$ & $39.11^{\circ}$ \\
\hline North PM & normal & 2421 & $-3.27^{\circ}$ & $38.94^{\circ}$ \\
\hline \multicolumn{5}{|c|}{ Experiment II (23 July -21 August, 1973) } \\
\hline East AM & normal & 682 & $-1.17^{\circ}$ & $41.95^{\circ}$ \\
\hline East PM & normal & 653 & $-0.68^{\circ}$ & $39.86^{\circ}$ \\
\hline North AM & normal & 683 & $+1.92^{\circ}$ & $41.23^{\circ}$ \\
\hline North PM & normal & 698 & $-0.67^{\circ}$ & $38.54^{\circ}$ \\
\hline West AM & normal & 469 & $-0.27^{\circ}$ & $42.58^{\circ}$ \\
\hline West PM & normal & 459 & $+1.73^{\circ}$ & $39.73^{\circ}$ \\
\hline South AM & normal & 490 & $-0.49^{\circ}$ & $41.07^{\circ}$ \\
\hline South PM & normal & 454 & $-1.86^{\circ}$ & $40.30^{\circ}$ \\
\hline \multicolumn{5}{|c|}{ Experiment III (22 August - 28 September, 1973) } \\
\hline East AM & normal & 678 & $-1.03^{\circ}$ & $40.52^{\circ}$ \\
\hline East AM & negated & 594 & $+1.01^{\circ}$ & $38.30^{\circ}$ \\
\hline East PM & normal & 661 & $-2.90^{\circ}$ & $37.75^{\circ}$ \\
\hline East PM & negated & 672 & $-1.70^{\circ}$ & $38.74^{\circ}$ \\
\hline North AM & normal & 696 & $+0.45^{\circ}$ & $38.60^{\circ}$ \\
\hline North AM & negated & 597 & $-0.85^{\circ}$ & $38.70^{\circ}$ \\
\hline North PM & normal & 674 & $-0.97^{\circ}$ & $39.16^{\circ}$ \\
\hline North PM & negated & 668 & $-4.53^{\circ}$ & $36.91^{\circ}$ \\
\hline
\end{tabular}

Turning behavior of eels directed north and east was not significantly changed $(P>0.05)$ by negation of the horizontal component of the magnetic field (Experiment III, Table 2). This result is consistent with the finding that there were no directional differences in orientation. Together these three experiments indicate that the elvers were not orienting in response to the horizontal vector of the earth's magnetic field.

The turning angles were also examined for temporal differences. Analyses of variance revealed no significant differences in response between the morning and afternoon sessions.

\section{Turning angles, electric field}

In the first two experiments elvers showed a distinct tendency to turn more to the right, i. e. toward the anode, the higher the electric field intensity (Table 3, 4). This 
turning behavior was found in both fresh and salt water, but the trend was more clear cut in fresh water. In both cases the mean turning angle of control elvers was intermediate, with elvers tested at low intensities turning less than controls, and those tested at higher intensities turning more.

When the electric field polarity was reversed in fresh water the turning of the elvers was also reversed (Table 3). The higher the intensity the more they turned left, again toward the anode. However, none of the mean turning angles was significantly different from the others (Table 4). Inexplicably the control elvers turned most to the left.

Excluding the controls, 11 of 13 mean turning angles fit the trend of increased turning toward the anode with increased electric field intensity.

Table 3

Turning angles of freshwater and saltwater elvers in weak electric fields. Turning to the right of $0^{\circ}$ is indicated by positive means, and to the left by negative means

\begin{tabular}{|c|c|c|c|}
\hline $\begin{array}{c}\text { Test } \\
\text { intensity } \\
\left(\mu \mathrm{A} / \mathrm{cm}^{2}\right)\end{array}$ & $\begin{array}{l}\text { Number of } \\
\text { observations }\end{array}$ & Mean angle & $\begin{array}{l}\text { Standard } \\
\text { deviation }\end{array}$ \\
\hline \multicolumn{4}{|c|}{ Fresh water, cathode left* (5 June -12 August, 1974) } \\
\hline $\begin{array}{l}\text { Control } \\
10^{-2} \\
10^{-1} \\
10^{0} \\
10^{1} \\
10^{2}\end{array}$ & $\begin{array}{l}920 \\
360 \\
600 \\
920 \\
560 \\
320\end{array}$ & $\begin{array}{r}6.55^{\circ} \\
-1.46^{\circ} \\
2.79^{\circ} \\
4.27^{\circ} \\
10.42^{\circ} \\
12.72^{\circ}\end{array}$ & $\begin{array}{l}41.99^{\circ} \\
38.29^{\circ} \\
42.41^{\circ} \\
43.52^{\circ} \\
45.61^{\circ} \\
47.51^{\circ}\end{array}$ \\
\hline \multicolumn{4}{|c|}{ Salt water, cathode left* (5 June -12 August, 1974) } \\
\hline $\begin{array}{l}\text { Control } \\
10^{-2} \\
10^{-1} \\
10^{0} \\
10^{1} \\
10^{2}\end{array}$ & $\begin{array}{l}920 \\
360 \\
540 \\
920 \\
560 \\
380\end{array}$ & $\begin{array}{r}3.78^{\circ} \\
1.35^{\circ} \\
-0.22^{\circ} \\
4.55^{\circ} \\
4.44^{\circ} \\
7.49^{\circ}\end{array}$ & $\begin{array}{l}40.07^{\circ} \\
38.85^{\circ} \\
35.58^{\circ} \\
40.74^{\circ} \\
41.98^{\circ} \\
47.80^{\circ}\end{array}$ \\
\hline \multicolumn{4}{|c|}{ Fresh water, cathode right (13 August - 23 August, 1974) } \\
\hline $\begin{array}{l}\text { Control } \\
10^{-2} \\
10^{0} \\
10^{2}\end{array}$ & $\begin{array}{l}360 \\
360 \\
360 \\
360\end{array}$ & $\begin{array}{l}-4.60^{\circ} \\
-0.43^{\circ} \\
-1.22^{\circ} \\
-1.67^{\circ}\end{array}$ & $\begin{array}{l}52.58^{\circ} \\
52.52^{\circ} \\
54.82^{\circ} \\
53.85^{\circ}\end{array}$ \\
\hline
\end{tabular}

Table 4

Significant differences among ranked mean turning angles of elvers in various intensity electric fields according to Duncan's new multiple range test $(P<0.05)$. Intensity in $\mu \mathrm{A} / \mathrm{cm}^{2}$. Intensity levels not underscored by the same line are significantly different

\begin{tabular}{|c|c|c|c|c|c|c|}
\hline Fresh water, cathode left & $10^{2}$ & $10^{x}$ & Control & $10^{\circ}$ & $10^{-1}$ & $10^{-2}$ \\
\hline Salt water, cathode left & $10^{2}$ & $10^{\circ}$ & $10^{1}$ & Control & $10^{-1}$ & $10^{-2}$ \\
\hline Fresh water, cathode right & $10^{-2}$ & $10^{\circ}$ & $10^{2}$ & Control & & \\
\hline
\end{tabular}




\section{Directional choices, magnetic field}

The 50 elvers used in the maze experiments collectively made 43,415 appearances. During a 5 min trial the number of appearances ranged from 1-188 and averaged 45 . The activity level of any individual was relatively consistent among test days and between the two trials of a daily session.

No preferences for any of the channels aligned with a particular geographic direction were exhibited in either a normal magnetic field or in one with a negated horizontal component (Table 5). The failure to appear in one geographic direction more frequently than the others and the absence of a change in directional choices when the magnetic field was altered indicates that the eels were not using the horizontal vector to orient. Supporting this conclusion is the fact that all Chi-square values for individual trials and for 10 day composites of individual eels were non-significant (Table 5).

Table 5

The number of turns in each geographic direction for the 10 day composite data for each test group of 10 eels. $\left(\chi^{2} 0.05=5.99\right)$

\begin{tabular}{|c|c|c|c|c|c|c|c|}
\hline \multirow{2}{*}{ Group } & \multirow{2}{*}{ Date } & \multirow{2}{*}{$\begin{array}{l}\text { Horizontal } \\
\text { geomagnetic } \\
\text { vector }\end{array}$} & \multicolumn{4}{|c|}{ Number of appearances } & \multirow[b]{2}{*}{ Chi-square } \\
\hline & & & Total & East & SSW & NNW & \\
\hline 1 & 19 Oct-5 Nov & $\begin{array}{l}\text { normal } \\
\text { negated }\end{array}$ & $\begin{array}{l}3026 \\
2806\end{array}$ & $\begin{array}{r}1035 \\
937\end{array}$ & $\begin{array}{r}1000 \\
942\end{array}$ & $\begin{array}{l}991 \\
927\end{array}$ & $\begin{array}{l}1.09 \\
0.12\end{array}$ \\
\hline 2 & 6 Nov-16 Nov & $\begin{array}{l}\text { normal } \\
\text { negated }\end{array}$ & $\begin{array}{l}4596 \\
4608\end{array}$ & $\begin{array}{l}1519 \\
1543\end{array}$ & $\begin{array}{l}1535 \\
1526\end{array}$ & $\begin{array}{l}1542 \\
1539\end{array}$ & $\begin{array}{l}0.18 \\
0.10\end{array}$ \\
\hline 3 & 17 Nov-27 Nov & $\begin{array}{l}\text { normal } \\
\text { negated }\end{array}$ & $\begin{array}{l}4983 \\
4442\end{array}$ & $\begin{array}{l}1665 \\
1493\end{array}$ & $\begin{array}{l}1661 \\
1450\end{array}$ & $\begin{array}{l}1657 \\
1499\end{array}$ & $\begin{array}{l}0.02 \\
0.97\end{array}$ \\
\hline 4 & $28 \mathrm{Nov}-7 \mathrm{Dec}$ & $\begin{array}{l}\text { normal } \\
\text { negated }\end{array}$ & $\begin{array}{l}6135 \\
5863\end{array}$ & $\begin{array}{l}2045 \\
1983\end{array}$ & $\begin{array}{l}2015 \\
1926\end{array}$ & $\begin{array}{l}2075 \\
1954\end{array}$ & $\begin{array}{l}0.29 \\
0.83\end{array}$ \\
\hline 5 & $9 \mathrm{Dec}-21 \mathrm{Dec}$ & $\begin{array}{l}\text { normal } \\
\text { negated }\end{array}$ & $\begin{array}{l}3169 \\
3721\end{array}$ & $\begin{array}{l}1065 \\
1232\end{array}$ & $\begin{array}{l}1037 \\
1234\end{array}$ & $\begin{array}{l}1067 \\
1255\end{array}$ & $\begin{array}{l}0.53 \\
0.25\end{array}$ \\
\hline Total & $19 \mathrm{Oct}-21 \mathrm{Dec}$ & $\begin{array}{l}\text { normal } \\
\text { negated }\end{array}$ & $\begin{array}{l}21909 \\
21440\end{array}$ & $\begin{array}{l}7329 \\
7188\end{array}$ & $\begin{array}{l}7248 \\
7078\end{array}$ & $\begin{array}{l}7332 \\
7174\end{array}$ & $\begin{array}{l}0.62 \\
1.00\end{array}$ \\
\hline
\end{tabular}

In contrast, elver turning more to the right or left was significant $(P<0.05)$ in $37.3 \%$ of the 904 individual trials with a least 1 turn (i. e. 2 appearances). The 10 day composite data of 33 of the 50 eels revealed significant tendencies to turn right or left in one or both of the magnetic fields (Table 6). These significant tendencies occurred with equal frequency in the normal field and in the field with the negated horizontal component. Of the 19 eels that made an overall significant number of right or left turns in both magnetic fields all but 2 (eels AF and AR, Table 6) turned in the same direction. The consistency of turning by individual animals is further indicated by the observation that most of the overall significant Chi-square values for right and left turns resulted from individual fish making more turns in the same direction on several test days. 


\section{Table 6}

Daily counts of right and left turning of elvers showing overall significant turning tendencies. $R=$ number of right turns and $L=$ number of left turns

\begin{tabular}{|c|c|c|c|c|c|c|}
\hline \multirow[b]{2}{*}{ Eel } & \multirow[b]{2}{*}{$\mathrm{R}>\mathrm{L}$} & \multirow[b]{2}{*}{ R sig. $>\mathrm{L}$} & \multicolumn{2}{|c|}{ Number of days } & \multirow[b]{2}{*}{$\begin{array}{l}\text { Significant } \\
\text { runs test }\end{array}$} & \multirow[b]{2}{*}{$\begin{array}{l}\text { Significant runs } \\
\text { test and chi-square }\end{array}$} \\
\hline & & & $L>R$ & L sig. $>\mathrm{R}$ & & \\
\hline \multicolumn{7}{|c|}{ Right turning, normal magnetic field } \\
\hline A & 8 & 6 & 1 & 1 & 4 & 3 \\
\hline $\mathrm{G}$ & 6 & 2 & 1 & 0 & 0 & 0 \\
\hline I & 6 & 4 & 2 & 0 & 4 & 2 \\
\hline $\mathrm{M}$ & 5 & 4 & 3 & 1 & 2 & 2 \\
\hline $\mathrm{Z}$ & 9 & 5 & 1 & 1 & 5 & 4 \\
\hline $\mathrm{AA}$ & 8 & 5 & 1 & 0 & 4 & 2 \\
\hline $\mathrm{AE}$ & 9 & 5 & 1 & 0 & 1 & 0 \\
\hline $\mathrm{AI}$ & 6 & 5 & 4 & 1 & 5 & 3 \\
\hline $\mathrm{AK}$ & 6 & 5 & 4 & 2 & 7 & 4 \\
\hline $\mathrm{AO}$ & 6 & 4 & 4 & 1 & 2 & 2 \\
\hline $\mathrm{AU}$ & 7 & 5 & 2 & 0 & 0 & 0 \\
\hline $\mathrm{AW}$ & 6 & 4 & 4 & 0 & 2 & 1 \\
\hline \multicolumn{7}{|c|}{ Right turning, negated horizontal vector } \\
\hline A & 7 & 3 & 2 & 0 & 3 & 1 \\
\hline B & 4 & 1 & $\overline{1}$ & 0 & 0 & 0 \\
\hline$G$ & 2 & 2 & 5 & 0 & 0 & 0 \\
\hline I & 6 & 4 & 2 & 0 & 1 & 0 \\
\hline $\mathrm{M}$ & 6 & 4 & 3 & 1 & 4 & 3 \\
\hline $\mathrm{R}$ & 8 & 5 & 2 & 1 & 8 & 4 \\
\hline $\mathrm{Z}$ & 6 & 5 & 3 & 0 & 4 & 2 \\
\hline $\mathrm{AA}$ & 7 & 2 & 3 & 1 & 3 & 0 \\
\hline $\mathrm{AD}$ & 7 & 2 & 1 & 0 & 3 & 2 \\
\hline $\mathrm{AE}$ & 8 & 2 & 2 & 0 & 1 & $\overline{0}$ \\
\hline $\mathrm{AF}$ & 5 & 3 & 5 & 2 & 4 & 2 \\
\hline $\mathrm{AI}$ & 8 & 4 & 2 & 1 & 3 & 2 \\
\hline $\mathrm{AK}$ & 9 & 6 & 1 & 1 & 8 & 5 \\
\hline $\mathrm{AO}$ & 9 & 6 & 1 & 1 & 5 & 5 \\
\hline $\mathrm{AR}$ & 2 & 1 & 5 & 1 & 1 & 1 \\
\hline $\mathrm{AU}$ & 10 & 3 & 0 & 0 & 1 & 1 \\
\hline AV & 10 & 2 & 0 & 0 & 3 & 1 \\
\hline AW & 6 & 4 & 4 & 2 & 6 & 4 \\
\hline \multicolumn{7}{|c|}{ Left turning, normal magnetic field } \\
\hline $\mathrm{E}$ & 0 & 0 & 2 & 1 & 0 & 0 \\
\hline $\mathrm{F}$ & 3 & 0 & 6 & 3 & 3 & 1 \\
\hline $\mathrm{L}$ & 1 & 0 & 9 & 7 & 2 & 1 \\
\hline $\mathrm{N}$ & 3 & 0 & 6 & 3 & 2 & 1 \\
\hline $\mathrm{Q}$ & 3 & 0 & 6 & 0 & 3 & 0 \\
\hline $\mathrm{T}$ & 4 & 1 & 5 & 4 & 4 & 2 \\
\hline $\bar{U}$ & 3 & 1 & 7 & 4 & 8 & 5 \\
\hline $\mathrm{V}$ & 3 & 2 & 5 & 3 & 2 & 0 \\
\hline$Y$ & 2 & $\overline{1}$ & 7 & 5 & 7 & 5 \\
\hline$\hat{\mathrm{AF}}$ & 1 & 1 & 8 & 5 & 8 & 5 \\
\hline $\mathrm{AM}$ & 1 & 0 & 8 & 3 & 8 & 3 \\
\hline AN & 1 & 0 & 9 & 3 & 5 & 2 \\
\hline $\mathrm{AR}$ & 2 & 0 & 5 & 1 & 0 & 0 \\
\hline $\mathrm{AT}$ & 1 & 0 & 9 & 5 & 3 & 0 \\
\hline
\end{tabular}


Table 6 (continued)

\begin{tabular}{|lcccccc|}
\hline Eel & R $>$ L & R sig. $>$ L & L $>$ R & L sig. $>$ R & $\begin{array}{c}\text { Significant } \\
\text { runs test }\end{array}$ & $\begin{array}{c}\text { Significant runs } \\
\text { test and chi-square }\end{array}$ \\
\hline \multicolumn{7}{c}{ Left turning, negated horizontal vector } \\
F & 4 & 1 & 5 & 4 & 4 & 2 \\
Q & 1 & 1 & 8 & 2 & 1 & 0 \\
S & 2 & 0 & 8 & 4 & 8 & 3 \\
T & 3 & 1 & 7 & 5 & 2 & 1 \\
X & 3 & 3 & 6 & 4 & 4 & 1 \\
Y & 4 & 1 & 5 & 1 & 2 & 1 \\
AM & 4 & 2 & 6 & 6 & 8 & 0 \\
AX & 4 & 1 & 5 & 4 & 2 & \\
\hline
\end{tabular}

The runs test analysis revealed that $30.8 \%$ of the individual trials had sequences of turns that were not made randomly. Of the 278 significant trials, $92.4 \%$ had too few runs. Observations of the eels suggest that many of the non-random sequences resulted from their tendency to swim along the walls of the channels, following the contours of the apparatus probably by visual or tactile stimuli. While such tendencies undoubtedly confound efforts to determine the extent of right and left handedness, the phenomenon could be a real one. Only $37.4 \%$ of the individual trials with significant Chi-square values also had significant runs tests, suggesting that many of the elvers that made significantly more right or left turns were not biased in the above manner.

\section{DISCUSSION}

\section{Electromagnetic field orientation}

The absence of changes in orientational responses to directional and temporal differences, as well as experimental alteration, of the earth's magnetic field indicates that either elvers of American eels were not sensitive to magnetic stimuli of natural intensities or they did not respond to them with overt changes in turning behavior. The results are consistent with the inability of Rommel \& MCCleave (1973a) to condition a cardiac deceleration in older American eels in response to changes in the horizontal or vertical components of geomagnetism.

Our results are in contrast, however, with those of investigations of European eels recently reported by Russian workers. Identical mazes were used in their studies and ours. Small European eels showed a preference for a particular geographic direction in the earth's magnetic field but the preference disappeared when the magnetic field was experimentally eliminated (BRANOver et al., 1971; GleYzer, 1971; GLEYZER \& KHODORKOVsKiY, 1971). The preferred direction changed with geographic location with eels in Kaliningrad and Odessa appearing more frequently in the E-W channels and eels in Leningrad appearing more frequently in the SSW-NNE channels (BRANOVER et al., 1971). Furthermore, the performance of the eels was modified by placing bar 
magnets in various positions relative to the apparatus (KfrodorkovskiY \& PolonNIKov, 1971).

The maze experiments of the present study were performed in an effort to duplicate some of the European elver results with American elvers. Unfortunately, many of the details regarding holding conditions and experimental procedures were not specified in the European elver studies. Information omitted included light intensity, salinity and water temperature in the apparatus, method of recording data, light regime, whether the fish were obtained in fresh or salt water, length of time they were held in the laboratory and the season in which the tests were conducted. Consequently, the procedures followed here undoubtedly differed in one or more of these aspects. Apparantly at least some of their experiments were conducted in the dark (KHoDoRKOVSKIY \& PoLONNIKov, 1971). Whether these differences are sufficient to account for the radically different turning behavior of the elvers cannot be determined. Our arena. studies provide additional negative evidence. However, it seems unlikely that these two eel species have different orientation mechanisms.

Possibly our experimental procedures were inappropriate to reveal any orientation to the earth's magnetic field. This seems a distinct possibility in view of the evidence presented by TEsch \& LeLEK (1973a, b). In a darkened circular chamber in which European eels could head in any direction, TEsch \& LELEK found that migratory and non-migratory adults, and to a lesser extent, elvers exhibited preferred directional headings. In further experiments TESCH (1974) showed that migrating adult eels significantly shifted the direction of their orientation when the horizontal component of geomagnetism was compensated.

VASIL'YEV \& GLEYZER (1972) found that locomotor activity of European elvers increased in increasing magnetic fields if the salinity was also increased, and TEscH (1974) found altered directional preferences of adults in salt water compared to those in fresh water. Our negative findings in fresh water may be because the elvers' first oceanic migration was already completed and orientation to the magnetic field was no longer needed. These elvers, though retaining an ability to detect magnetic stimuli, might not respond by overt body orientation. We are currently conducting experiments in darkness and salt water with elvers readapted to salt water.

The electric field experiments in the arena lend further support to the hypothesis that American eels orient to electric fields such as generated by ocean currents. The lowest electric field in salt water we tested $\left(10^{-2} \mu \mathrm{A} / \mathrm{cm}^{2}\right.$, Table 3$)$ is similar to that found in the Gulf Stream (Rommel \& McCleave, 1973b). While our results are not unequivocal, they do suggest that the elvers' movement is influenced by weak electric fields and that the direction of influence depends on the polarity of the electric fields. Since the mean turning angle of the control group in fresh water, cathode right, is not similar to the other two control group means, and since the electric fields were mostly stronger than expected in the ocean, nothing can be speculated about the biological significance of the observed turning directions. More complete studies with weaker fields are planned.

When the published work of various workers is examined, the conclusion must be reached that somehow both American and European eels are able to extract orientational information from the earth's magnetic field. However, there is evidence for 
and against all three hypotheses of how this information is extracted. Further research using a variety of experimental techniques is necessary to help resolve the question.

\section{Turning preferences}

The tendency for right or left turning exhibited by many of the eels in the maze was not in response to the presence or absence of the horizontal magnetic vector. Preferences occurred with equal frequency in the two experimental fields. Neither right nor left turning predominated in the sample as a whole, although individuals were consistent in their behavior.

Right- and left-handed turning tendencies have been noted in other fish. SPENCER (1939) reported that four of seven goldfish, Carassius auratus, tended to turn right. KLEEREKOPER et al. (1970) found that four goldfish were significantly left-handed and one was significantly right-handed during a continuous $11 \mathrm{~h}$ interval. The probability that two consecutive turns would be in the same direction was consistently greater than the probability that they would be in the opposite direction. Handedness was also displayed by Diplodus sargus and Scyliorbinus stellaris in a compartmentalized tank, even in the absence of directional cues (KLEEREKOPER, 1967). This diversity of fishes exhibiting handedness suggests that the right and left turning tendencies observed in some of the eels in the present study might be a real phenomenon.

These turning tendencies, if oriented by visual cues in the illuminated maze, would have masked the expression of any potential response to geomagnetism. Experiments now being conducted in darkness should determine if that were so.

\section{SUMMARY}

1. Turning angles of American eel elvers in a circular arena were the same when the horizontal vector of the earth's magnetic field was parallel to the body axis and when the horizontal vector was perpendicular to it.

2. No difference in turning was exhibited by elvers directed either north, east, south or west in an arena or E-W, NNE-SSW or NNW-SSE in a maze.

3. Turning behavior in both experimental chambers was unaltered by negation of the horizontal component of the earth's magnetic field.

4. Elvers in a square arena, in both fresh and salt water, turned more toward the anode the stronger the horizontal electric field. Reversal of the polarity of the electric field reversed the direction of turning.

5. While the results are preliminary, they suggest that elvers do not utilize the geomagnetic field directly, but that they may utilize oceanic electric fields for orientation.

6. A predominance of right or left turning by many of the elvers in the maze suggests they might be "handed", but the possibility that this handedness phenomenon was an artifact of the apparatus cannnot be eliminated. 
Acknowledgements. We thank Mr. E. H. AlBeRT for technical assistance and many helpful thoughts; Mr. R. Fontaine, Ms. N. Famous, and Ms. K. Stred for making many of the observations and coding data for computer analysis; and the numerous persons who helped collect elvers. Computer time was supplied by Computing and Data Processing Services of the University of Maine. This investigation was supported by NIH research grant number NS : 11276 from National Institute of Neurological Diseases and Stroke to J. D. McCleave.

\section{LITERATURE CITED}

Bertin, L., 1956. Eels - a biological study. Cleaver-Hume, London, 192 pp.

Branover, G. G., Vasil'yev, A. S., Glexzer, S. I. \& Tsinober, A. B., 1971. A study of the behavior of the eel in natural and artificial and magnetic fields and an analysis of its reception mechanism. J. Ichthyol. [Vop. Ikhtiol.] 11, 608-614.

Brown, F. A. Jr., BretT, W. J., Bennett, M. F. \& Barnwell, F. H., 1960. Magnetic response of an organism and its solar relationship. Biol. Bull. mar. biol. Lab., Woods Hole 118, $367-381$.

Creutzberg, F., 1958. Use of tidal streams by migrating elvers (Anguilla vulgaris TurT.). Nature, Lond. 181, 857-858.

- 1959. Discrimination between ebb and flood tide in migrating elvers (Anguilla vulgaris TUR T.) by means of olfactory perception. Nature, Lond. 184, 1961-1962.

- 1963. The role of tidal streams in the navigation of migrating elvers (Anguilla vulgaris TurT.). Ergebn. Biol. 26, 118-127.

Deelder, C. L., 1952. On the migration of the elver (Anguilla vulgaris TurT.) at sea. J. Cons. perm. int. Explor. Mer 18, 187-218.

GLEYZER, S. I., 1971. Early ontongeny of the non-conditioned reactions of eel (Anguilla anguilla) to the natural magnetic field of the earth. Trans. Atlant. Res. Inst. Fish. Oceanogr. 36, 64-71.

- \& KHodorkovskiY, V. A., 1971. Experimental determination of geomagnetic perception in the European eel. Rep. Acad. Sci. USSR 201, 964-967.

Harden Jones, F. R., 1968. Fish migration. Arnold, London, 325 pp.

KhodorkovskiY, V. A. \& Polonnikov, R. I., 1971. On the study of ultraweak magnetic receptions in fish. Trans. Atlant. Sci. Res. Inst. Fish. Oceanogr. 36, 72-77.

KLeEREKoper, H., 1967. Some aspects of olfaction in fishes, with special reference to orientation. Am. Zool, 7, 385-395.

- Timms, A. M., Westlake, G. F., Davy, F. B., Maler, T. \& Anderson, V. M., 1970. An analysis of locomotor behavior of goldfish (Carassius auratus). Anim. Behav. 18, 317-330.

MnLEs, S. G., 1968. Rheotaxis of elvers of the American eel (Anguilla rostrata) in the laboratory to water from different streams in Nova Scotia. J. Fish. Res. Bd Can. 25, 1591-1602.

Murray, R. W., 1962. The response of the ampullae of Lorenzini of elasmobranchs to electric stimulation. J. exp. Biol. 39, 119-128.

REGNART, H. C., 1932. The generation of electric currents by water moving in a magnetic field. Proc. Durham Univ. phil. Soc. 8, 291-300.

Rommel, S. A. Jr. \& McCleave, J. D., 1972. Oceanic electric fields: Perception by American eels? Science, N. Y. 176, 1233-1235.

- 1973a. Sensitivity of American eels (Anguilla rostrata) and Atlantic salmon (Saimo salar) to weak electric and magnetic fields. J. Fish. Res. Bd Can. 30, 657-663.

- 1973b. Prediction of oceanic electric fields in relation to fish migration. J. Cons. perm. int. Explor. Mer 35, 27-31.

Royce, W. F., Smith, L. S. \& Hartt, A. C., 1968. Models of oceanic migrations of Pacific salmon and comments on guidance mechanisms. Fishery Bull. Fish Wildl. Serv. U.S. 66, $441-462$.

Sokal, R. R. \& Rohlf, F. J., 1969. Biometry. Freeman, San Francisco, 776 pp.

SPENCER, W. P., 1939. Diurnal activity rhythms in fresh-water fishes. Ohio J. Sci. 39, 119-132. 
TESCH, F.-W., 1974. Influence of geomagnetism and salinity on the directional choice of eels. Helgoländer wiss. Meeresunters. 26, 382-395.

- \& LELEK, A., 1973a. Directional behavior of transplanted stationary and migratory forms of the eel, Angtilla anguilla, in a circular tank. Neth. J. Sea Res. 7, 46-52.

- 1973b. An evaluation of the directional choice in the eel, in captivity. Arch. FischWiss. 24, 237-251.

Thornton, W. M., 1932. Electrical perception by deep sea fish. Proc. Durham Univ. Phil. Soc. 8, 301-312.

VAsIL'YEV, A. S. \& GleyzER, S. I., 1973. Changes in the activity of the freshwater eel [Anguilla anguilla (L.)] in magnetic fields. J. Ichthyol. [Vop. Ikhtiol.] 13, 322-324.

Second author's address: Dr. J. MCCleAve

Department of Zoology

University of Maine

Orono, Maine 04473

USA 